\title{
Changes in volunteering among young old in the Netherlands between 1992 and 2002: the impact of religion, age-norms, and intergenerational transmission
}

\author{
Bianca Suanet · Marjolein Broese van Groenou • \\ Arjan W. Braam
}

Received: 17 September 2008/ Accepted: 8 July 2009/Published online: 12 August 2009

(C) The Author(s) 2009. This article is published with open access at Springerlink.com

\begin{abstract}
The positive trend in volunteering among the Dutch young old may in part be due to a relatively favorable disposition to volunteer. Using data from the Longitudinal Aging Study Amsterdam, volunteering rates of 55-64 year olds in 1992 and 2002 were compared and associated with (among others) three types of dispositional factors: religious involvement, age-related engagement norms, and parental socialization. The recent cohort was less religiously involved, but more supportive of social engagement at older age, and more often had parents who volunteered, were religiously involved or higher educated. Multivariate analyses revealed that cohort differences were largely explained by cohort differences in educational level and religious involvement. It is concluded that their lower religious level suppresses the volunteering rate of the current young old. To compensate for the decline in religious young old, family and the broader society will become more important for stimulating volunteer work in the future.
\end{abstract}

Keywords Volunteer - Young old C Cohort comparison . Religion · Socialization

B. Suanet · M. Broese van Groenou ( $\square$ )

Department of Sociology, Faculty of Social Sciences,

VU University, Boelelaan 1081, 1081 HV Amsterdam,

The Netherlands

e-mail: mi.broese@fsw.vu.nl

\section{A. W. Braam}

Altrecht Mental Health Care, Utrecht, The Netherlands

\section{A. W. Braam}

Institute for Research in Extramural Medicine (EMGO),

VU Medical Centre, van der Boechorststraat 7,

1081 BT Amsterdam, The Netherlands

\section{Introduction}

Several decades ago, it was predicted that the social engagement of young olds would increase due to their relatively good health and freedom from work and family responsibilities (Neugarten 1996). Empirical evidence supports this prediction as trend studies show a positive engagement in later life. Putnam (2000) reported that, in contrast to a general decline in social engagement of the general population in the US, most recent cohorts of older people had increased engagement in volunteer organizations. This trend was also observed in northern-European countries as Sweden (Agahi and Parker 2005), Finland (Pohjolainen 1991) and the Netherlands (Knulst and Van Eijck 2006). Explanations of this rise have been limited to the increased educational level and changed employment status of the young old (e.g. Pohjolainen 1991; Knulst and Van Eijck 2006) as these factors are important determinants of volunteering. However, volunteering is in general associated with three types of determinants (e.g. Wilson 2000); the level of personal capacities (such as education and health), restrictions in the social context (such as paid employment and living arrangements), and the disposition to volunteer (as indicated by attitudes and norms). Due to the emphasis on capacities and structural context in earlier studies, the effect of dispositional factors on volunteering among young old received less attention (Choi 2003). Therefore, in this study, we will focus on to what degree cohort differences in dispositional factors explain cohort differences in volunteer work, in addition to differences in individual resources and structural opportunities.

Disposition refers in general to behavioral intentions reflecting attitudes and norms that guide human behaviour (Azjen 1988). Although, intentions are also reliant on perceived opportunities to perform certain behavior, we 
focus on norms and attitudes rather than perceived opportunities as determinants of volunteering behaviour. People's disposition to volunteer is stronger when they feel responsible for the wellbeing of others and are committed to invest time and energy in social actions that benefits others more than themselves. Basically, such social commitment and altruistic behaviour is transmitted in socialization processes. Family, school, voluntary organisations, neighborhood and the religious community are social environments in which volunteering is learned, expected and appreciated. Empirical evidence shows that religious beliefs and church attendance are positively associated with volunteering (e.g. Wilson and Musick 1997) and that volunteering runs in families across generations (e.g. Bekkers 2007). In this study, the individual's religious involvement as well as family socialization, i.e. the intergenerational transmission of status and norms, is considered important indicators of the disposition to volunteer.

However, considering that we focus on young olds, we should also take societal views on older people into account. Popular opinion now is that old age can be a "successful" or "productive" phase of life (Rowe and Kahn 1997). This view may enhance societal expectations towards young old to spend their (large) amounts of free time in volunteering activities. Therefore, our third indicator of the disposition to volunteer concerns age-specific engagement norms.

In sum, our study focuses on three social environments in which the disposition to volunteer can be transmitted: the family, the religious group, and the society at large. As religious involvement is declining, and family ties have loosened in a society where personal relationships are more volatile, these changes should have led to a decrease of volunteering among young olds. On the other hand, as agespecific social engagement may have favoured the young old over time, this should have benefited the volunteering rates of young olds. Data are used from two birth cohorts in the Longitudinal Aging Study Amsterdam; the 55-64 year olds in 2002 and the same age group in 1992. Within this 10 -year time frame, we aim to disentangle to what degree cohort differences in volunteering rates are due to cohort differences in religious involvement, intergenerational transmission, and age-specific engagement norms. Specific hypotheses will be developed further below.

\section{Religious involvement}

In the Netherlands, between the end of the nineteenth century and the mid twentieth century, most domains of life, politics, welfare and health, were segregated by religious and ideological demarcations. This also applied to social and leisure activities, which helped to generate to large networks of sympathizers that were willing to volunteer (De Hart 1999b). However, the processes of secularization and the declining social significance of religion marked the end of this period of pillarization (Stark and Iannaconne 1994). Older adults from younger cohorts are less often adhering to a religious denomination, irrespective of the type of affiliation (Lalive d'Epinay et al. 2001). In addition, according to a recent study in the Netherlands, the proportion of people above 60 years who attends church at least once every 2 weeks has decreased from just above $70 \%$ in 1965 to approximately 55\% in 2005 (Becker and De Hart 2006).

By participating in church activities, one builds a dense social network and a normative framework and acquires social and civic skills that promote volunteering (Smidt 1999). Denomination is also important as population studies showed that Calvinists (Protestants) are more inclined to volunteer than Catholics (Smidt 1999). It has been suggested that the less hierarchical structure and the smaller congregations of the Calvinist churches compared to the Catholic Church offer larger possibilities for common church members to be active within their congregations. Additionally, it is argued that Calvinists lay more emphasis on the social responsibility of the individual than Catholics (De Hart 1999a). As church attendance may be more directly benefiting to volunteering than affiliation per se, due to the involvement in normative networks, practising Calvinist young olds will be most likely to volunteer, followed by Catholic practising, then Calvinist and Catholic non-practising, while those without affiliation are least likely to be active. Considering our cohort differences, this leads to the hypothesis that cohort differences in volunteering are in part explained by the cohort differences in the proportion of practising and non-practising Calvinist and Catholics.

\section{Intergenerational transmission}

In research on intergenerational transmission, two theories have been proposed to explain similarities in volunteering between parents and their (adult) children: family socialization theory and family status transmission theory (Janoski and Wilson 1995; Mustillo et al. 2004). Based on the family socialization theory, conformity in normative orientations concerning volunteer work of parents and their children is expected. This is the more so as the family is considered to be the most important value socialization mechanism (Bengtson 1975) and altruistic behaviour is strongly influenced by the presence of a positive role model that can be learned from and be imitated (Bandura 1977). This is corroborated by empirical studies showing that, both in young adulthood and in mid-life, children of parents that volunteered, are more likely to volunteer themselves (Janoski and Wilson 1995; Mustillo et al. 2004). The 
transmission of volunteering norms may be even stronger in religious families (Park and Smith 2000). Bekkers (2007) showed that strong religious socialization and having parents with a Calvinist denomination result in higher levels of volunteering for, respectively, pillarized (religion-based) associations and secular associations. Between the end of the nineteenth century and the midtwentieth century, voluntary associational life knew its heyday in the Netherlands (De Hart 1999b). There was a large increase in memberships of different voluntary associations between 1930 and 1960, ranging from sports associations to trade unions. Thus, the late cohort is more likely to have had parents that were actively involved in voluntary associations and this should be favorable for their own volunteering. However, the parents of the late cohort are also somewhat less likely to be religiously involved, as the proportion of the population that had no church membership increased from $14 \%$ in 1930 to $18 \%$ in 1960 .

The status transmission theory suggests that children of parents who have a high socio-economic status are more likely to volunteer (Janoski and Wilson 1995; Mustillo et al. 2004). Related to Weberian theory, it is assumed that parents with a higher social status bestow their children with more social, economic, and cultural resources and offer them a position in the social structure that is more conducive to volunteering. Many studies showed that education is the most important socio-economic resource when it concerns volunteering (e.g. Wilson 2000). Since 1900, the average level of education obtained by both woman and men has increased in every 10-year cohort. This implies that parents from the late cohort have attained on average a higher level of education than the parents of early cohort (Liefbroer and Dykstra 2000). Therefore, in addition to the higher prevalence of volunteering parents, the higher level of education of their parents can possibly partly explain the recent increase in volunteering among young olds. In contrast, the decreasing religious involvement of the parents should have lowered the volunteering rate of the late cohort.

Trends in age-related engagement norms

For many decades, the stereotypes of older persons as sick, isolated, needy and loosing competence have been strong and pervasive (Neugarten 1996). According to some scholars, older adults are more recently being framed in the public discourse as active autonomous as this can help to maximize their economic, political and social potential (Martinson and Minkler 2006). This change of perception in the public discourse on older adults is likely to have an impact on their self-perception. It is therefore plausible that today's young old will increasingly perceive being a volunteer as appropriate or desirable role for themselves given that work and family responsibilities are limited in this age group. A cohort-study in Switzerland showed that disengagement decreased sharply over the past decades: the percentage of 64-75 years old that agrees with the statement 'the best place for people like themselves is at home' has fallen from $47 \%$ in 1979 to $20 \%$ in 1994 (Lalive d'Epinay et al. 2001). In addition, older adults that feel that they are too old to volunteer are less likely to volunteer than those that do not see themselves as incapable or redundant as a result of their age (Warburton et al. 2001). If age-related disengagement norms are losing strength, today's young olds will be more inclined to volunteer.

Individual resources and social context

This study emphasizes dispositional factors of volunteering, but will also take account of the personal resources and social opportunity structures that are well-known determinants of volunteering. In other work, we examined the relative impact of changes in educational level, health status, partner status, and employment on cohort changes in various forms of social participation (Broese van Groenou 2006; Broese van Groenou and Deeg 2006). In this study, these four factors, as well as sex and age, will be regarded as control variables and will not be discussed at great length.

\section{Method}

Sample

The data used for this study are from the Living arrangements and Social Networks of Older Adults (LSN) and Longitudinal Aging Study Amsterdam (LASA). In 1992, for LSN face-to-face interviews were conducted among 3805 respondents between age 55 and 85 on topics as basic demographics, subjective and functional health status, personal network, loneliness, and well-being (Knipscheer et al. 1995). The sample is stratified by sex and age and drawn from the registers of 11 municipals that vary in terms of region and level of urbanization. About 9 months later, LASA initiated a first follow up study, which was followed by subsequent observations in 1995/1996, 1998/ 1999, 2001/2002, and 2005/2006 (Deeg et al. 2002). During the first measurement in 1992, the response among respondents between 55 and 64 years of age was $62 \%$. In 2002/2003, a new sample was drawn from the same 11 municipals. The response rate was $57 \%$. The LASA data collected in 1992 and 2002 consists of a face-to-face interview on demographic, psychical, cognitive, emotional, and social functioning, a written questionnaire, and a medical interview with clinical measurements. 
This study compares two birth cohorts: respondents born between 1928 and 1937 (early cohort, 55-64 year old in 1992/1993, $N=998$ ) and respondents born between 1938 and 1947 (recent cohort, 55-64 year old in 2002/2003, $N=1002$ ). The LSN-study was only used for the information on the parental background of the early cohort. As this information is asked retrospectively, the use of both LSN and LASA data for the 1992 cohort is not likely to result in serious distortions of the results. Due to missing values on relevant variables, respectively, 957 and 994 respondents were the units of analyses.

\section{Measurements}

Volunteer work is indicated by a binary variable whether the respondent was active in executive boards and/or conducted chores within one or more voluntary associations. The respondent was first asked whether he/she was member of one or more voluntary associations. If the respondent gave a positive answer, a question was asked on whether he/she was active in executive boards (for example chair or treasurer) or conducted chores (for example making coffee or organizing contests). A positive response to either one or both questions was considered as volunteering ( 0 'no' and 1 'yes').

For the religious involvement of the respondent, information on the church membership and frequency of attending religious services were combined into a single measure. After recoding church membership, the denomination 'Calvinist' included members of the main Protestant denominations with origins in the Calvinist doctrines (Dutch Reformed Churches, Reformed Calvinist and other more strict orthodox or Calvinist congregations, Braam et al. 1998). Very small groups, such as Jewish, Islamic, and humanistic associations were coded as 'other'. The frequency of church attendance ranges from 1 'never' to 6 'weekly or more'. Those attending church at least 2-3 times a month are considered practising, while those attending church less often are considered non-practising. In combination with the various denominations, this results in the following categories: 0 'no church membership', 1 'Calvinist practising', 2 'Calvinist non-practising', 3 'Roman Catholic practising', 4 'Roman Catholic nonpractising' and 5 'other'.

Father's church membership is based on a measure indicating the church membership of the respondent's father during their youth. The categories are recoded into: 0 'no church membership', 1 'Calvinist', 2 'Roman Catholic, 3 'other', 4 'unknown'. Only the church membership of the father is incorporated in the analysis to avoid multicollinearity with mother's church membership $(r=0.80)$. Given the very high correlation between mother and father's church membership, for 14 respondents for which father's church membership was missing, but mother's church membership was available, father's church membership was imputed with mother's membership to reduce missing values.

Mother's volunteer work is indicated by a categorical indicating variable whether or not the respondent had a mother that did volunteer work when the respondent was age 14: 0 'no', 1 'yes' and 2 'unknown'. There is no information on father's volunteer work available.

The social status of the family is indicated by the educational level of the most educated parent. From the original nine categories an indicator is constructed that consists of four categories: 1 'low level of education' (elementary school not completed and elementary school), 2 'middle level of education' (lower vocational education, general intermediate education, intermediate vocational education) and 3 'higher level of education' (general secondary education, higher vocational education, college education and university education) and 4 'unknown'.

Engagement norms are measured by a dichotomous variable assessing whether the respondent agrees or disagrees with the statement that paid work is only useful until a certain age ( 0 'agree and no opinion' and $1=$ 'disagree'). Disagreement with this statement indicates that age should not be a limitation for social engagement. It should be noted here that paid work is not the same as volunteer work, and it is likely that one disagrees with paid work at older age and not with volunteering at older age. The agerelated norm on volunteering was only available in the 1992 data-set and correlated weakly with the paid-work norm $(r=0.19)$. Still, due to the lack of measurement of a volunteer-norm in 2002, we used the paid-work norm as a proxy for age-specific engagement norms.

In line with the educational attainment of the parents, the respondent's level of education is coded in three categories: 1 'low level of education' 2 'middle level of education' and 3 'higher level of education'. As indicator for health status, a measure of functional limitations was used. Respondents were asked to report the ability to perform three activities of daily living (ADL): walking the stairs, cutting one's toenails and using public transport. For each of the three activities, the respondents reported whether they could perform the activity 0 'without problems', 1 'with some trouble', 2 'only with help' or 3 'not at all'. The sum score of these items is used ranging from 0 to 9 . The employment status is specified by the hours that the respondent works each week: 0 'no paid work', 1 '1-20 h (part-time)' and 2 'more than $21 \mathrm{~h}$ paid work per week (full-time)'. The partner status is indicated by living with a spouse or partner: 0 'no' and 1 'yes'. Finally, age at the date of the interview, ranging from 55 to 64 years, and sex ( 0 'male' and 1 'female'), are incorporated in the analysis as control variables. 


\section{Procedure}

To determine whether there are cohort differences with respect to volunteering and its determinants, chi square tests and $t$ tests are performed. In addition, the associations between all independent variables and volunteering are examined in the total sample. Since the dependent variable for volunteering is dichotomous, multivariate logistic regression will be used to determine the explanatory value of the independent variables and six models will be tested. In the first model, only cohort and the control variables age and sex are incorporated in the analysis. In the second to the fifth model, respectively, the determinants for individual capacities (level of education and functional limitations) and structural context (partner status and paid employment), religious involvement, engagement norms, and lastly intergenerational transmission (mother's volunteer work, church membership of parents and highest level of education parents) are entered. For model 3-5, exploratory analysis is conducted to explore whether there are interaction effects between cohort and the indicators, implying that the effect of these determinants differ by cohort. None of the interaction terms was found to be significant, so they are not included in the full model and not discussed in the results. In the sixth model, all independent variables are incorporated.

\section{Results}

\section{Cohort differences}

At first, the focus will be on the differences in characteristics between the two cohorts. The results are outlined in Table 1. The recent cohort (born between 1938 and 1947) volunteers substantially more often compared to the early cohort (born between 1928 and 1937). In the recent cohort, $43 \%$ performs volunteer work, which is $37 \%$ in the early cohort. The results also show that the recent cohort has a higher level of education and stronger engagement norms. In addition, older adults from the recent cohort more often have a father with a church membership, a mother that does volunteer work, and at least one parent that has a middle or high level of education. Concerning religiosity, there is an overall tendency towards no church membership and nonpractising church memberships among Calvinists and Catholics. In addition, older adults in the recent cohort report (slightly) more functional limitations. In addition, the recent cohort is more often employed, both in part-time and full-time jobs, than the early cohort. There are no cohort-differences in partner status, sex, and age.

Next, bivariate associations between the determinants and volunteering are estimated. Older volunteers differ from non-volunteers in several characteristics (Table 1). Volunteers are more often male and have a partner than non-volunteers. In addition, volunteers have better capacities, as a higher level of education and lower functional limitations. There is no difference between volunteers and non-volunteers in terms of their employment status. Regarding dispositional factors, it is found that especially Calvinist practicing older adults are more likely to volunteer, followed by the Catholic practising. Non-practising Calvinist or Catholic differed less in volunteering, indicating that church attendance is more important than affiliation. There are considerable differences with regard to parental background: older volunteers more often had a Calvinist father, a mother that did volunteer work, and at least one parent that held a middle level of education. Older volunteers do not differ from non-volunteers in terms of engagement norms.

\section{Explaining cohort differences in volunteering}

The multivariate logistic regression analyses indicate to what extent cohort differences in volunteering are due to cohort differences in religiousness, intergenerational transmission or engagement norms. The results of Model 1 (Table 2) show that older adults in the recent cohort are significantly more likely to volunteer than older adults in the early cohort, controlled for sex and age (OR = 1.24). In Model 2, level of education, functional limitations, employment status and partner status are added, which results in a minor decrease in the difference in volunteering $(\mathrm{OR}=1.20)$. The absence of large change in cohort-differences in the odds of volunteering is caused by two contradictory developments in individual capacities. The higher functional limitations in the recent cohort increase the cohort differences, while the higher level of education of the recent cohort decreases, and thus explains, the cohort difference. The structural context measures, employment status and partner status of the older adults add little to the explanation of cohort-differences in voluntary associations.

In Model 3, religious involvement of the respondent is added instead. This results in a strong increase in the cohort differences in volunteering $(\mathrm{OR}=1.42)$. The results imply that given equal levels of religious involvement in both cohorts, the volunteering rate of the recent cohort would be even about $42 \%$ higher than in the early cohort. The decreasing proportion of practicing Calvinist and Catholic strongly suppresses the rise in volunteering in the younger cohort.

Model 4 shows that the cohort differences in engagement norms, as present in the bivariate associations, do not explain the cohort difference in volunteering. The OR of Model 4 is similar to the OR of Model 1, and the cohort difference is still statistically significant. 
Table 1 Differences in characteristics of older adults between cohorts and between volunteers and non-volunteers

\begin{tabular}{|c|c|c|c|c|c|c|}
\hline & $\begin{array}{l}\text { Cohort } 1928-1937 \\
(N=957)\end{array}$ & $\begin{array}{l}\text { Cohort } 1938-1947 \\
(N=994)\end{array}$ & $\begin{array}{l}P \\
\left(\chi^{2} / t\right)\end{array}$ & $\begin{array}{l}\text { Non-volunteer } \\
(N=1159)\end{array}$ & $\begin{array}{l}\text { Volunteer } \\
(N=792)\end{array}$ & $P\left(\chi^{2} / t\right)$ \\
\hline Volunteer $(\%)$ & 38 & 43 & 0.01 & & & \\
\hline Female $(0-1)(\%)$ & 52 & 53 & 0.84 & 57 & 46 & 0.00 \\
\hline Average age (55-64 years) & 60.3 & 60.0 & 0.09 & 60.1 & 60.1 & 0.62 \\
\hline \multicolumn{7}{|c|}{ Highest attained educational level respondent } \\
\hline Low $(\%)$ & 32 & 21 & 0.00 & 32 & 19 & 0.00 \\
\hline Middle (\%) & 51 & 55 & & 51 & 55 & \\
\hline High $(\%)$ & 17 & 24 & & 17 & 27 & \\
\hline Functional limitations (0-9) & 0.3 & 0.5 & 0.00 & 0.4 & 0.3 & 0.00 \\
\hline \multicolumn{7}{|l|}{ Employment status } \\
\hline No paid job (\%) & 72 & 58 & 0.00 & 66 & 62 & 0.09 \\
\hline 1-20 h each week (part-time) $(\%)$ & 9 & 14 & & 12 & 11 & \\
\hline$>20 \mathrm{~h}$ each week (full-time) $(\%)$ & 19 & 29 & & 22 & 27 & \\
\hline With partner $(\%)$ & 82 & 84 & 0.25 & 81 & 86 & 0.00 \\
\hline \multicolumn{7}{|l|}{ Religious involvement } \\
\hline No church member (\%) & 40 & 48 & 0.00 & 51 & 35 & 0.00 \\
\hline Calvinist practicing $(\%)$ & 18 & 13 & & 9 & 24 & \\
\hline Calvinist non-practising (\%) & 9 & 11 & & 11 & 9 & \\
\hline Roman Catholic practising (\%) & 13 & 5 & & 8 & 12 & \\
\hline Roman Catholic non-practising (\%) & 16 & 19 & & 19 & 16 & \\
\hline Other $(\%)$ & 3 & 4 & & 3 & 5 & \\
\hline \multicolumn{7}{|l|}{ Church membership father } \\
\hline No church membership & 28 & 20 & 0.00 & 27 & 20 & 0.00 \\
\hline Calvinist & 32 & 33 & & 28 & 40 & \\
\hline Roman Catholic & 36 & 33 & & 35 & 34 & \\
\hline Other & 3 & 6 & & 5 & 5 & \\
\hline Unknown & 2 & 7 & & 6 & 2 & \\
\hline \multicolumn{7}{|l|}{ With mother that volunteered (\%) } \\
\hline No & 74 & 72 & 0.00 & 74 & 71 & 0.00 \\
\hline Yes & 17 & 22 & & 17 & 23 & \\
\hline Unknown & 9 & 6 & & 9 & 6 & \\
\hline \multicolumn{7}{|l|}{ Highest educational level parents } \\
\hline Low & 53 & 50 & 0.00 & 54 & 48 & 0.01 \\
\hline Middle & 25 & 33 & & 27 & 33 & \\
\hline High & 7 & 11 & & 9 & 9 & \\
\hline Unknown & 15 & 6 & & 11 & 9 & \\
\hline With engagement norms $(0-1)(\%)$ & 72 & 85 & 0.00 & 78 & 80 & 0.28 \\
\hline
\end{tabular}

The indicators of intergenerational transmission are added in Model 5, which leads to a very small decrease in the cohort-difference in volunteering compared to Model 1 $(\mathrm{OR}=1.21$ and $\mathrm{OR}=1.24$, respectively). This minor decrease is mainly due to the higher educational level and volunteering of the parents in the recent cohort, but this analysis shows that these differences do not add much to our understanding of the differences in volunteering.

In the full Model 6, the cohort difference has about the same magnitude as Model 3 that only incorporates the religious involvement of the young olds $(\mathrm{OR}=1.43)$.
The results indicate that the negative effects of decreasing religiosity more than compensate for the positive effect of the increased level of education in the younger cohort. Being Calvinist practicing or Roman Catholic practicing increases the odds of volunteering by, respectively, 4.71 and 2.82, while having a high level of education increases the odds by 2.68 , showing the importance of practicing church memberships for volunteering.

The indicators for intergenerational transmission loose their significance due to the incorporation of 
Table 2 The relative importance of cohort, individual capacities, structural context, religion, parental background and engagement norms for volunteering

\begin{tabular}{|c|c|c|c|c|c|c|}
\hline & \multicolumn{6}{|l|}{ OR } \\
\hline & Model 1 & Model 2 & Model 3 & Model 4 & Model 5 & Model 6 \\
\hline Cohort & $1.24 *$ & 1.20 & $1.45^{* * *}$ & $1.22 *$ & $1.21 *$ & $1.43 * * *$ \\
\hline Female $(0-1)$ & $0.64 * * *$ & $0.73 * *$ & $0.57 * * *$ & 0.64 & $0.62 * * *$ & $0.64 * * *$ \\
\hline Average age (55-64 years) & 0.99 & 1.00 & 0.99 & 1.00 & 1.00 & 1.00 \\
\hline \multicolumn{7}{|c|}{ Highest attained educational level respondent } \\
\hline Low & & 1 & & & & 1 \\
\hline Middle & & $1.66 * * *$ & & & & $1.59 * *$ \\
\hline High & & $2.33 * * *$ & & & & $2.68 * * *$ \\
\hline Functional limitations $(0-9)$ & & $0.81 * *$ & & & & $0.86^{*}$ \\
\hline \multicolumn{7}{|l|}{ Employment status } \\
\hline No paid employment & & 1 & & & & 1 \\
\hline $1-20 \mathrm{~h}$ each week & & 0.92 & & & & 0.88 \\
\hline$>20 \mathrm{~h}$ each week & & 0.93 & & & & 0.89 \\
\hline Partner status (no, yes) & & 1.28 & & & & 1.19 \\
\hline \multicolumn{7}{|l|}{ Religious involvement } \\
\hline No church member (ref.) & & & 1 & & & 1 \\
\hline Calvinist practicing & & & $4.57 * * *$ & & & $4.72 * * *$ \\
\hline Calvinist non-practising & & & 1.35 & & & 1.36 \\
\hline Roman Catholic practising & & & $2.71 * * *$ & & & $2.82 * * *$ \\
\hline Roman Catholic non-practising & & & 1.25 & & & 1.28 \\
\hline Other & & & $2.22 * * *$ & & & $2.60 * * *$ \\
\hline Engagement norms $(0-1)$ & & & & 1.09 & & 1.07 \\
\hline \multicolumn{7}{|l|}{ Church membership father } \\
\hline No church membership & & & & & 1 & 1 \\
\hline Calvinist & & & & & $1.91 * * *$ & 1.07 \\
\hline Roman Catholic & & & & & $1.31 *$ & 1.03 \\
\hline Other & & & & & 1.26 & 0.81 \\
\hline Unknown & & & & & 0.53 & 0.51 \\
\hline \multicolumn{7}{|l|}{ Mother's volunteer work } \\
\hline No & & & & & 1 & 1 \\
\hline Yes & & & & & $1.36^{*}$ & 1.23 \\
\hline Unknown & & & & & 0.91 & 0.77 \\
\hline \multicolumn{7}{|l|}{ Highest educational level parents } \\
\hline Low & & & & & 1 & 1.25 \\
\hline Middle & & & & & $1.36^{* *}$ & 0.84 \\
\hline High & & & & & 1.07 & 1.31 \\
\hline Unknown & & & & & 0.48 & 0.18 \\
\hline Nagelkerke $R^{2}$ & 0.02 & 0.06 & 0.11 & 0.02 & 0.06 & 0.16 \\
\hline
\end{tabular}

*** $p<0.001, * * p<0.01, * p<0.05$

individual characteristics of the older adults. Additional stepwise analyses show that mother's volunteer work and father's church membership become non-significant once religious involvement of the respondent is included in the model. The effect of having parents' of with a middle level of education looses significance due to incorporation of the young olds own level of education.

\section{Conclusion and discussion}

The study investigated to what degree current young olds are more likely to volunteer than young olds a decade ago. The results indicate that there is indeed a rise in the proportion of volunteers among young olds, but the change is not very large. Expressed in odds, the late cohort is only about one-fifth more likely to volunteer than the early 
cohort. Still, the increase is considerable and our study showed that it is in part explained by the increased educational level of the late cohort. However, the increase is strongly suppressed by the lower religious denomination and involvement and, to a lesser degree, by the lower functional capacities of the late cohort. Parental background and engagement norms do differ among these birth cohorts but only indirectly add to our understanding of why current young olds volunteer more often than their predecessors. The results suggest that, although future cohorts of older adults may have a stronger inclination towards volunteer work from their youth due to religious involvement, educational level and volunteer work of their parents, it is more important that they have a high level of education and practising church memberships themselves.

Furthermore, the results suggest that, regarding volunteering, socialization in religious groups is more important than in families or the society at large. The positive effect of religious involvement on volunteering behaviour is notable. On the one hand, this effect can be interpreted as a tautology, since opportunities to volunteer itself are often linked to involvement in these religious associations. On the other hand, religious involvement reflects a normative framework that may induce volunteering in all types of voluntary organisations, not only in religious based organisations. In part, this issue could have been solved by looking more closely at the organisations in which one volunteers, but our data does not distinguish between volunteering for pillarized, i.e. ideology and religion based, and secular voluntary associations (Bekkers 2007). Bekkers reports that religious upbringing is only associated with volunteer work in traditional pillarized organisations, whereas post materialistic values drive volunteering in secular organizations. These post materialistic views may be reflected in parental educational level and respondents' own educational level. Our study shows positive effects of religious affiliation as well as of parental and own educational level on volunteering, suggesting that these factors predict volunteering in different types of organisations. Thus, the relatively large impact of religious affiliation on volunteering reflects both the opportunities and the normative framework to volunteer in (supposedly) religious based organisations.

Given the decline in religious involvement in the general population, non-affiliated persons should be embedded in alternative social and normative structures, if volunteering among young olds is to keep rising. The disposition to volunteer can also be strengthened by involvement in the neighborhood and local organizations. However, such strong bonds are usually not found among neighbors and members of sport associations, so it is not likely that volunteering will be learned and reinforced only in these social environments. Socialization within the family is still needed to lay a firm basis for volunteering in later life. Our results show that parental background is important, as in particular the volunteering of the mother is significantly associated with volunteering of young olds. Parents pass on altruism and resources and therefore intergenerational transmission remains essential. Although the distinction in three social structures (church, family, and society) proved useful, an additional explanation for volunteering among the young old should also be sought among more general dispositional factors, like altruism and empathic concern (Bekkers 2007).

Contrary to our expectations, the stronger social engagement norms in the younger cohort did not explain cohort-differences in volunteering. Still, we feel that the society at large remains a significant source for reinforcing volunteering among the young old. The fact that we did not find an impact of engagement norms on volunteering can be due to two reasons. First, people within the age between 55 and 64 might be too young to be influenced by the effects of age-related disengagement norms. These norms are more likely to have an impact at higher ages. Second, the finding that age-related engagement norms do not predict volunteering could be a shortcoming of our measurement instrument, as other studies did find an effect of age-related volunteering norms (Warburton et al. 2001). Therefore, in future research, more attention should be drawn to find suitable measurements for age-specific norms concerning volunteer work in order to determine whether these can explain the recent rise in volunteering among young olds.

Although we investigated volunteer work among young old in one European country only, namely the Netherlands, we believe that our results are also applicable to other European countries, in particular to western and northern Europe. A recent European study on volunteering showed that volunteering rates were relatively high in the Scandinavian countries and the Netherlands and lower in southern European countries (Erlinghagen and Hank 2006). Despite differences in volunteering among European countries, trends in educational level, health and a decline in religious involvements are also present in other European countries (e.g. Lalive d'Epinay et al. 2001), and may result in the same positive trend in volunteering among the young old.

The present study compared two cohorts at one point in time. With this cross-sectional approach, we cannot draw conclusions on individual change in volunteering among young olds over time. Ideally, cohort-sequential designs that follow multiple cohorts and have panel renewal over time (De Vaus 2001) are especially desirable to study changes in volunteering among older adults, since they can help to distinguish whether changes in volunteering among older adults are due to aging, period, or cohort effects. LASAfollow ups on the late cohort allow such comparisons in the near future. In addition, due to the unavailability of more detailed questions on volunteering, we used a dichotomous measure of volunteering. In future research, using a more 
sophisticated scale on volunteering is particularly salient, as projections point out that although the number of volunteering older people will increase in the next cohorts, their contributions are likely to be more irregular and less timeintensive than before (Dekker et al. 2007; Einolf 2009).

In the current era, government policy refrains from influencing the private domain and stimulates volunteering more indirectly. In order to attract young olds as volunteer, government, employers and voluntary associations could promote the view of the young old as a socially active group and try to create an environment in which volunteering is supported and highly esteemed. Local organisations could cooperate in initiating and continuing existing volunteer programmes for this age group. In doing so, they should emphasize the benefits of volunteering for both the volunteer as well as the broader social context. Such actions may increase the visibility of young olds in society and could contribute to the rise of social engagement of future generations.

Acknowledgments The Longitudinal Aging Study Amsterdam is financed for a large part by the Ministry of Health, Wellbeing and Sport. This research was supported by a grant of the Dutch Society for Scientific Research (NWO-MaGW, 400-05-715).

Open Access This article is distributed under the terms of the Creative Commons Attribution Noncommercial License which permits any noncommercial use, distribution, and reproduction in any medium, provided the original author(s) and source are credited.

\section{References}

Agahi N, Parker MG (2005) Are today's older people more active than their predecessors? Participation in leisure-time activities in Sweden in 1992 and 2002. Ageing Soc 25:925-941

Azjen I (1988) Attitudes, personality, and behavior. Dorsey Press, Chicago

Bandura A (1977) Social learning theory. Prentice Hall, Englewood Cliffs

Becker J, De Hart J (2006) Godsdienstige veranderingen in Nederland: Verschuivingen in de binding met kerken en christelijke traditie (religious changes in the Netherlands). SCP, The Hague

Bekkers R (2007) Intergenerational transmission of volunteering. Acta Sociol 50:99-114

Bengtson V (1975) Generation and Family Effects in Value Socialization. Am Sociol Rev 40:358-371

Braam AW, Beekman ATF, Knipscheer CPM, Deeg DJH, van den Eeden P, van Tilburg W (1998) Religious denomination and depression among older Dutch citizens: patterns and models. J Aging Health 10:483-503

Broese van Groenou M (2006) Sociale participatie van 55-64 jarigen: is de huidige generatie sociaal actiever dan de vorige? [Social participation of 55-64-year olds: Is the current generation more socially active than their predecessor?]. T Gerontol Geriatr 37:218-225

Broese van Groenou M, Deeg DJH (2006) Cohort differences in social participation of the young old: the impact of individual resources and social context. Paper presented at the annual meeting of the Gerontological Society of America, Orlando, Florida, USA, November 2006
Choi L (2003) Factors affecting volunteerism among older adults. J Appl Gerontol 22:179-196

De Hart J (1999a) Godsdienst, Maatschappelijke Participatie en Sociaal Kapitaal. In: Dekker P (ed) Vrijwilligerswerk vergeleken [Voluntary work: a comparative study]. SCP, The Hague, pp 207-239

De Hart J (1999b) Lange termijn trends in lidmaatschappen en vrijwilligerswerk. In: Dekker P (ed) Vrijwilligerswerk vergeleken [Voluntary work; A comparative study]. SCP, The Hague, The Netherlands, pp 33-68

De Vaus D (2001) Research design in social research. Sage, London

Deeg DHG, Van Tilburg TG, Smit JH, De Leeuw ED (2002) Attrition in the longitudinal aging study Amsterdam: the effects of differential inclusion in side studies. J Clin Epidemiol 55:319328

Dekker P, de Hart J, Faulk L (2007) Toekomstverkenning Vrijwillige inzet 2015 [Volunteering up to 2015: a forward study]. SCP, The Hague, The Netherlands

Einolf C (2009) Will the boomers volunteer during retirement? comparing the baby boom, silent, and long civic cohorts. Nonprofit Volunt Sect Q 38:181-199

Erlinghagen M, Hank K (2006) The participation of older Europeans in volunteer work. Ageing Soc 26:567-584

Janoski T, Wilson J (1995) Pathways to voluntarism: family socialization and status transmission models. Soc Forces 74:271-292

Knipscheer C, de Jong Gierveld J, Van Tilburg T, Dykstra P (eds) (1995) Living arrangements and social networks of older adults. VU University Press, Amsterdam

Knulst W, Van Eijck K (2006) Old Soldiers never die. Explaining the disproportionate aging of volunteers in the Netherlands between 1985 and 2000. Acta Sociol 49:185-200

Lalive d'Epinay C, Maystre C, Bickel J (2001) Ageing and cohort changes in sports and psychical training from the golden decades onward: a cohort study in Switzerland. Soc Leis 24:453-481

Liefbroer A, Dykstra P (2000) Levenslopen in verandering: een studie naar ontwikkelingen in de levenslopen van Nederlanders geboren 1900 en 1970. [Changes in life courses: a study on the developments in the life courses of the Dutch born between 1900 and 1970]. Sdu Uitgevers, The Hague, The Netherlands

Martinson M, Minkler M (2006) Civic engagement and older adults: a critical perspective. Gerontologist 46:318-324

Mustillo S, Wilson J, Lynch SM (2004) Legacy volunteering: a test of two theories of intergenerational transmission. J Marriage Fam 66:530-541

Neugarten B (1996) The meanings of age: selected papers of Bernice L. Neugarten. University of Chicago Press, Chicago

Park J, Smith C (2000) "To Whom Much Has Been Given...": religious capital and community voluntarism among churchgoing protestants. J Sci Study 39:272-286

Pohjolainen P (1991) Social participation and life-style. A longitudinal and cohort study. J Cross Cult Gerontol 6:109-117

Putnam RD (2000) Bowling alone: the collapse and revival of American Community. Simon and Schuster, New York

Rowe JW, Kahn RL (1997) Successful aging. Gerontol 37:433-440

Smidt C (1999) Religion and civic engagement: a comparative analysis. Ann Am Acad Pol Soc Sci 565:176-192

Stark R, Iannaconne L (1994) A supply-side of the secularization of Europe. J Sci Study Relig 33:230-252

Warburton J, Terry D, Rosenman L, Shapiro M (2001) Differences between older volunteers and non-volunteers. Res Aging 23:586-605

Wilson J (2000) Volunteering. Ann Rev Soc 26:215-240

Wilson J, Musick M (1997) Who cares? Towards an integrated theory of volunteer work. Am Soc Rev 62:694-713 